\title{
Development of Physics Mobile Learning Based on Local Wisdom to Improve Vector and Diagram Representation Abilities
}

\author{
https://doi.org/10.3991/ijim.v12i6.8746 \\ Miftahul Husna and Heru Kuswanto( $(\varpi)$ \\ Univeritas Negeri Yogyakarta, Yogyakarta, Indonesia \\ herukus61@uny.ac.id
}

\begin{abstract}
The research aims to 1) develop a feasible physics learning media based on local wisdom (waterwheel); 2) measure the improvement of student's representation abilities after using of learning media based on local wisdom. The development of media used 4D model; (a) define, (b) develop, (c) design, and (d) disseminate. The feasibility of the learning media is obtained through expert validation and limited test. The improvement of the students' vector representation and diagram representation abilities was obtained through field test. The participants of field test were 25 students of experimental class and 25 students of control class in SMAN 3 Yogyakarta. The results show that the local wisdom-based learning media is feasible to use based on the expert validation and limited test. The gain score obtained from field test showed that that the learning media can improve the students' vector representation and diagram representation abilities.
\end{abstract}

Keywords-M-Learning, Local Wisdom, Learning Media, Vector Representation, Diagram Representation

\section{Introduction}

Nowadays, various learning media can be accessed in mobile, such as personal computing, communication, internet access and many others. All of them are accessible through mobile media. This leads to the common use of mobile media by the junior high school and senior high school students [1][2][3]. For this reason, teachers should utilize technology to create an effective, fun and challenging learning environment for students [1]. The multimedia applications created by the teachers themselves are precisely the effective teaching materials in education [4]. M-learning emerges as a potential medium to facilitate learning by supporting the communication between teachers and students, enabling flexible learning, enhancing the search and sharing of information, discussions and other features [5][6][7]. Due to those advantages, M-learning becomes a promising as well as challenging to be developed and implemented in learning.

In this study, the physics concepts was explained in one of Indonesian local wisdom. Kesiman and Agustini [8] stated that by studying and analyzing Indonesian culture, 
many local wisdom concepts found are still applicable in the society and can be utilized to support learning. Waterwheel is a local wisdom used by some Gunung Kidul local society to irrigate their rice fields. In this study, local wisdom is chosen as the source of contextual learning. By using local wisdom waterwheer in learning, teacher can explain physics concept with a familiar and close example to student. Rosengrant, Van and Etkina[9] stated that by exposing students to real learning in their daily life, both in terms of material exposure and problems or questions, will help students to improve their representational abilities. Therefore, the aim of using local wisdom based learning media is to improve the abilities of vector representation and diagram representation. To obtain the learning based on the local wisdom of waterwheels, it is necessary to choose the appropriate media to display representations such as verbal, diagrams, images, graphs in the form of animations and simulations which are clear and interesting to be understood by the students visually. The selection of m-learning is expected to be able to facilitate the needs for more interesting vector and diagram visual display in learning.

This paper explains the steps of this development research. For this purpose, this paper will be organized into some sections. Section 1 is to introduce the main idea as the background of the research. After that, these ideas are discussed more clearly through literature review in section 2 and research questions are stated in section 3. In section 4 methodology of research are discussed briefly, meanwhile the detail of design, development and assessment are explained in section 5 dan 6 . Finally, the result of development are discussed in section 7 and concluded in Section 8.

\section{Literature Review}

\subsection{Mobile Learning}

M-Learning is the use of media technology, wireless networks, and mobile phones to facilitate, support, enhance and expand learning achievement and the learning itself [10]. The use of m-learning in learning can contribute positively. Leeds [8] found that learning using m-learning can improve some students' average ability and enable the learning outside the classroom. One of the important components in m-learning is the operating system used. In designing appropriate m-learning the developer should consider who will use it, the type of media used and the operating system used as well as how to make it easily accessible [11]. This consideration is important in order to make the learning media meaningful, useful, involving students and user friendly. Thus, the development of m-learning requires a design which is applicable to atmosphere of learning and the students condition.

Studies on the use of m-learning using the android platform have been widely conducted recently. This is due to the rapid development of technology and the students' close familiarity with mobile devices. Mobile device such as smartphone was used for communication or access to information. Among the studies was a study conducted by Hwang et al [12]. The study used inquiry approach that is based on mobile learning. From the pre and post test, it was found that students who studied using inquiry 
approach that was based on mobile learning had better achievement and less cognitive load compared to those who studied using traditional approach. In terms of motivation, the use of android-based learning media can have a positive impact as indicated by the results of the study conducted by Lubis and Ikhsan [13]. They found that there was an increase in the students' motivation with the use of android learning media. The learning can be displayed more attractively and more fun by the learning media developed.

One of the important components in m-learning is the operating system used. Android is one of the open operating systems and application frameworks which is supported by Google that can be used as an m-learning platform. Android offers rich and innovative application development that supports audio and video formats [6]. The Android operating system has several advantages over other operating systems, including more flexible and more inclusive to distribute the applications. If students do not have android media, they can still use the application through a computer with an android emulator [2]. Due to those advantages, selected as the operating system in this study.

\subsection{Local Wisdom of Waterwheel}

Some parties defined local wisdom as the value of knowledge. In addition, this wisdom has a useful value and has been accumulated for years or generations in different societies with diverse and distinct historical backgrounds [14][15][16]. Liliweri [17] defined local wisdom as traditional knowledge which is the cumulative body of knowledge of a group about life practices as well as interactions with nature and the environment that have been entrenched within the society. Machmud [18] explained that local wisdom emerges as a community effort to solve problems with the environment. Thus, local wisdom can be defined as the values of knowledge in society that have been validly tested in a distinct local context. This values are useful in the practice of everyday life and have been inherited from generation to generation.

Waterwheel is a local wisdom used by some local society in Gunung Kidul, Yogyakarta. For Javanese society, agriculture is one of main element of their culture because most of them belong to the primary economic sector [19]. The rice farmers independently in group built a waterwheel to irrigate their fields. The waterwheel main components are wheel, bamboo tubes and pedals. Most of components are made from wood and bamboo which are easily obtained from surrounding environtment. The waterwheel can overcome irrigation problem in dry season. In addition, the use of the natural components is more economical and environmentally friendly than the use of water pumping machines. The activities of building a waterwheel in group also create harmony and cooperation among society.

In construction and how waterwheel works, there are physics concepts such as circular motion, gears circular motion, potential energy, kinetic energy, volume flow rate and continuity equation. From this fact, using local wisdom waterwheel as a base of learning is not an impossible thing to do. A study by Azizahwati et al [20] that the use of local wisdom as a basis in learning can provide a positive impact on the learning outcomes of physics science. In addition, including local wisdom content in learning gives some advantages, such as, presenting contextual learning [21][22], conserving and revitalizing local wisdom value [23], increasing students' awareness and 
participation about environmental issues, and introducing local and cultural wisdom that has not been known among younger generation [24]. Overall, integration of local wisdom in learning is expected not only to give impact to students but also become an effort to preserve the cultural value itself.

This study focus on the use of local wisdom to serve contextual learning. Local wisdom can be an example of real application of physics in daily life. Barniol \& Zalava [25] and Kustusch [26] suggest teachers should include context in the questions to explain the concept of physics. It can be from daily life context, for example a moving car or waterwheel, or from vector context directly. By exposing students to real learning with their everyday life both in terms of materials exposure and problems or questions provided, teachers can create rich representation. Some of the physics concepts that can be studied from the local wisdom of waterwheels are shown in Figure 1.

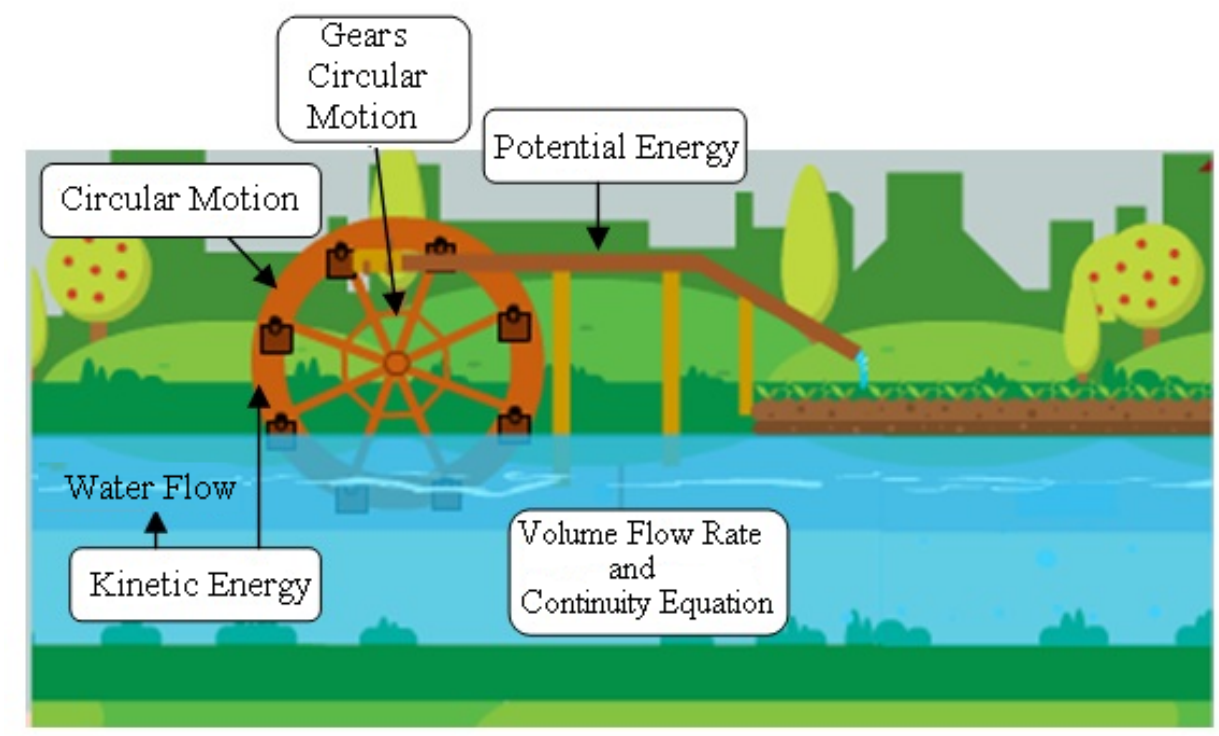

Fig. 1. Physics Concepts in Local Wisdom of Waterwheels

\section{$3 \quad$ Research Questions}

The purpose of developing this learning media is to produce android-assisted physics learning media based on local wisdom which is feasible to use in order to improve the multi-representation ability of the students. Therefore, the followings research questions can be formulated:

a) Is the developed learning media based on local wisdom feasible?

b) Is the developed learning media able to improve the students' vector representation and diagram representation abilities? 


\section{$4 \quad$ Research Methodology}

The development of the learning media was conducted using Research and Development method and followed the stages of 4-D development model by Thiagarajan, Semmel and Semmel [27]. 4-D model consists of Define, Design, Develop and Disseminate. Through these four stages, a product in the form of a valid learning media which has been through the limited test and field test stages was obtained.

a) Define : Analyzing needs of learning according to curriculum, student and class condition, and their knowledge about local wisdom. This stage is conducted through interview, class observation and preliminary survey.

b) Design : Designing learning media based on result from previous stage. Researcher formulated material based on local wisdom and made initial design of learning media in a storyboard.

c) Development : developing learning media using Adobe Flash Professional CS 6 and converting it into android mobile apps. In this stage, learning media was tested through expert validation, limited test and field test. after each test, learning media was revised based on the assessments. The tests conducted to obtain a feasible learning media.

d) Dissemination : Disseminating the learning media after it stated feasible.

\section{$5 \quad$ Design and Development of Learning Media}

The theoritical framework for the design and development of the learning media in this study was obtained from the synthesis of several sources. The indicators of the students' vector representation that want to be achieved were synthesized from Aguirre \& Erickson [28], Knight Randal D [29], and Nyuyen \& Meltzer [30]. Meanwhile, the indicators of diagram representation abilities were synthesized from Larkin \& Reif [31], Etkina et al, [32] and Rosengrant, Van and Etkina [9]. The framework of references are listed in Table 1.

The feasibility of the learning media is determined through expert validation, limited test and field test. Validation test was conducted by material experts, media experts, two physics teachers and four peer reviewers. Based on the validators assessment, learning media was revised. Next test was limited test on 22 students. In this test, the students do independent learning using the learning media and then asked to fill out an assessment questionnaire. The assessment of the field test subjects was used to make the second revision on the learning media. The last test was field test. In the field test, the learning media was used in the learning process in the treatment class. As a comparison, there was a control class that did not use the learning media. The participants were 50 students. They were 25 students in the experimental class and 25 students in the control class. They are 10th grade students of SMAN 3 Yogyakarta. Both classes were given pre-test before starting the treatment. The learning on circular motion materials was done for 2 weeks by the same teacher. After the learning was complete, the 
Paper-Development of Physics Mobile Learning Based on Local Wisdom to Improve Vector...

Table 1. Design and Development Framework based on Representation Indicators

\begin{tabular}{|c|c|c|}
\hline No & $\begin{array}{c}\text { Vector Representation } \\
\text { Indicators }\end{array}$ & Development in Media \\
\hline \multirow{4}{*}{1} & \multirow{4}{*}{$\begin{array}{l}\text { Describe and identify the } \\
\text { scalar and vector quanti- } \\
\text { ties }\end{array}$} & $\begin{array}{l}\text { Display images and animations that differentiate vector quantities and } \\
\text { scalar quantities in the circular motion of the waterwheels }\end{array}$ \\
\hline & & $\begin{array}{l}\text { Display direction explanation of each vector quantity by using arrow im- } \\
\text { ages and the right hand rule }\end{array}$ \\
\hline & & $\begin{array}{l}\text { Display the image of vector quantity with complete numbers and correct } \\
\text { direction, length and label }\end{array}$ \\
\hline & & $\begin{array}{l}\text { Provide examples of questions and solutions that describe and identify } \\
\text { the scalar and vector quantities }\end{array}$ \\
\hline \multirow{4}{*}{2} & \multirow{4}{*}{$\begin{array}{l}\text { Describe and calculate } \\
\text { vector quantities correctly } \\
\text { to perform the problem } \\
\text { solving }\end{array}$} & $\begin{array}{l}\text { Display the animations, interactions of the forces causing the circular } \\
\text { motion }\end{array}$ \\
\hline & & $\begin{array}{l}\text { Display explanation of centripetal acceleration direction to the center of } \\
\text { the circle with vector analysis }\end{array}$ \\
\hline & & $\begin{array}{l}\text { Analyze the different centripetal accelerations at each point on the pen- } \\
\text { dulum that is tied to the rope }\end{array}$ \\
\hline & & $\begin{array}{l}\text { Provide examples of problems and solutions that describe and identify } \\
\text { the scalar and vector quantities }\end{array}$ \\
\hline \multirow{4}{*}{3} & \multirow{4}{*}{$\begin{array}{l}\text { Interpret information } \\
\text { from a representation into } \\
\text { diagram representation to } \\
\text { solve the problem }\end{array}$} & Display circular motion diagram with quantities involved completely \\
\hline & & $\begin{array}{l}\text { Display animation of wheel-to-wheel relation on a waterwheel power } \\
\text { plant with a rotational speed corresponding to the spokes of the wheel }\end{array}$ \\
\hline & & $\begin{array}{l}\text { Explain the direction of centripetal acceleration motion toward the center } \\
\text { of the circle through the diagram }\end{array}$ \\
\hline & & $\begin{array}{l}\text { Display examples of question through animation and verbal explanation } \\
\text { as well as solutions that employ diagram representation }\end{array}$ \\
\hline \multirow{3}{*}{4} & \multirow{3}{*}{$\begin{array}{l}\text { Employ diagram repre- } \\
\text { sentation to determine in- } \\
\text { teraction in the system }\end{array}$} & $\begin{array}{l}\text { Display animation of wheel-to-wheel relation on a waterwheel power } \\
\text { plant with a rotational speed corresponding to the spokes of the wheel. }\end{array}$ \\
\hline & & $\begin{array}{l}\text { Explain the relation of linear velocity and the angular velocity of the } \\
\text { wheels which are interconnected through diagrams, animations and ver- } \\
\text { bal explanations }\end{array}$ \\
\hline & & $\begin{array}{l}\text { Display examples of problem through animation and verbal explanation } \\
\text { as well as solutions that determine interactions in the system }\end{array}$ \\
\hline
\end{tabular}

students were given a post-test to find out the students' representation ability after the learning. The improvement of students' representation ability was determined by gain score of each class. The gain score equation was written in equation (1), meanwhile the criteria of gain score presented in Table 2.

$$
g=\frac{S_{f}-S_{i}}{100-S_{i}}
$$

Table 2. Gain Score Criteria

\begin{tabular}{|l|l|l|}
\hline No. & \multicolumn{1}{|c|}{ Gain Score } & \multicolumn{1}{c|}{ Criteria } \\
\hline 1. & $g \geq 0,70$ & High \\
\hline 2. & $0,30 \leq g<0,70$ & Medium \\
\hline 3. & $g<0,30$ & Low \\
\hline
\end{tabular}




\section{Representation Abilities Assessment}

The assessment instrument of vector representation and diagram representation is 6 essay questions consisting of 3 vector representation problems and 3 diagram representation problems. Problems were developed based on the indicators in Table 1. Each indicator is elaborated into several sub-indicators as a problem-solving steps by using representation. In addition to explain the indicators, the sub-indicators are also used as the assessment criteria. Assessment used 1-5 scale to sum the number of problem solving steps conducted by the students. The assessment criteria for the vector and diagram representation abilities are shown in Table 3.

Table 3. Assessment Criteria of the Vector Representation and Diagram Representation Abilities

\begin{tabular}{|c|c|c|}
\hline No & $\begin{array}{l}\text { Vector Representation Assessment } \\
\text { Aspects / Problem Solving Steps }\end{array}$ & Scoring \\
\hline 1 & Describe vectors in complete amount & \multirow{5}{*}{$\begin{array}{l}1 \text { if } 1 \text { step is performed } \\
2 \text { if } 2 \text { steps are performed } \\
3 \text { if } 3 \text { steps are performed } \\
4 \text { if } 4 \text { steps are performed } \\
5 \text { if } 5 \text { steps are performed }\end{array}$} \\
\hline 2 & Describe vector direction correctly & \\
\hline 3 & $\begin{array}{l}\text { Describe vector length correctly / pro- } \\
\text { portionally }\end{array}$ & \\
\hline 4 & Label vectors correctly & \\
\hline 5 & $\begin{array}{l}\text { Identify scalar and vectors quantities } \\
\text { correctly }\end{array}$ & \\
\hline No & $\begin{array}{c}\text { Diagram Representation Assessment } \\
\text { Aspects / Problem Solving Steps }\end{array}$ & Scoring \\
\hline 1 & Make a diagram to solve the problem & \multirow{5}{*}{$\begin{array}{l}1 \text { if } 1 \text { step is performed } \\
2 \text { if } 2 \text { steps are performed } \\
3 \text { if } 3 \text { steps are performed } \\
4 \text { if } 4 \text { steps are performed } \\
5 \text { if } 5 \text { steps are performed }\end{array}$} \\
\hline 2 & $\begin{array}{l}\text { Draw the diagram components in- } \\
\text { volved with correct proportion }\end{array}$ & \\
\hline 3 & $\begin{array}{l}\text { Identify known physics quantities cor- } \\
\text { rectly }\end{array}$ & \\
\hline 4 & $\begin{array}{l}\text { Identify the relation of known physics } \\
\text { quantities correctly }\end{array}$ & \\
\hline 5 & $\begin{array}{l}\text { Perform problem solving from diagram } \\
\text { representation correctly }\end{array}$ & \\
\hline
\end{tabular}

\section{$7 \quad$ Results and Discussion}

\subsection{Learning Media}

The learning media was developed according to storyboard designed before. Storyboard is the initial script that becomes the outline of the media development. The learning media was developed using Adobe Flash Professional CS 6 software with action script 3. Furthermore, the learning media file was published to android with apk extension. This application can be installed on the android media for both smartphones and tablets. The tittle of learning media is KLASIKA : Kearifan Lokal dalam Pembelajaran Fisika (Local Wisdom in Physics Learning). Figure 2 is the display of the learning media interfaces. 

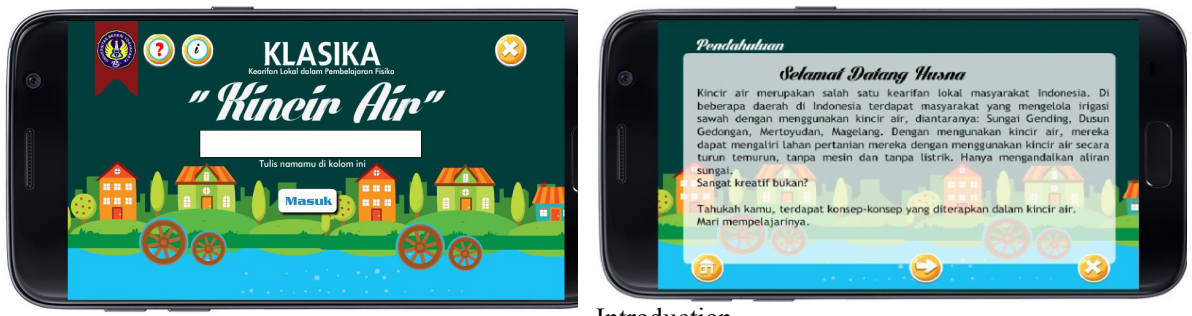

Login Menu

Introduction
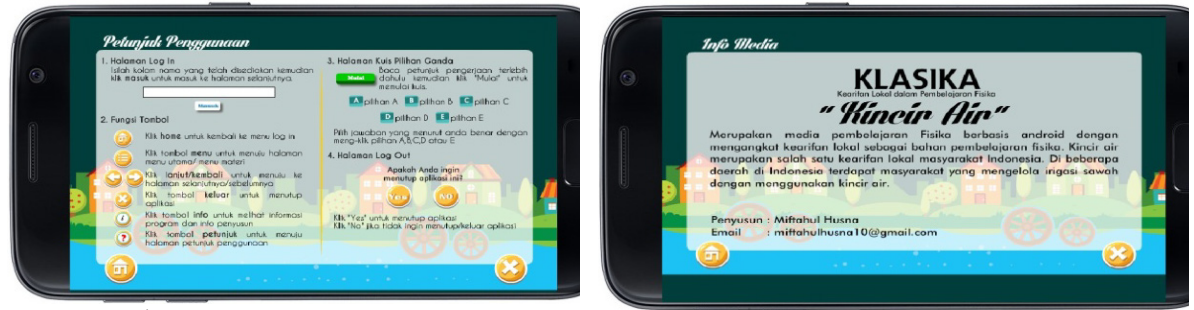

User Manual

Media Information

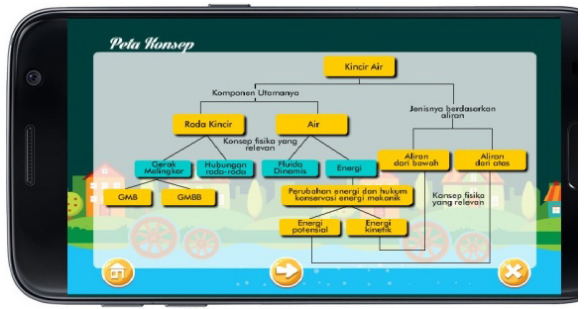

Concept Map
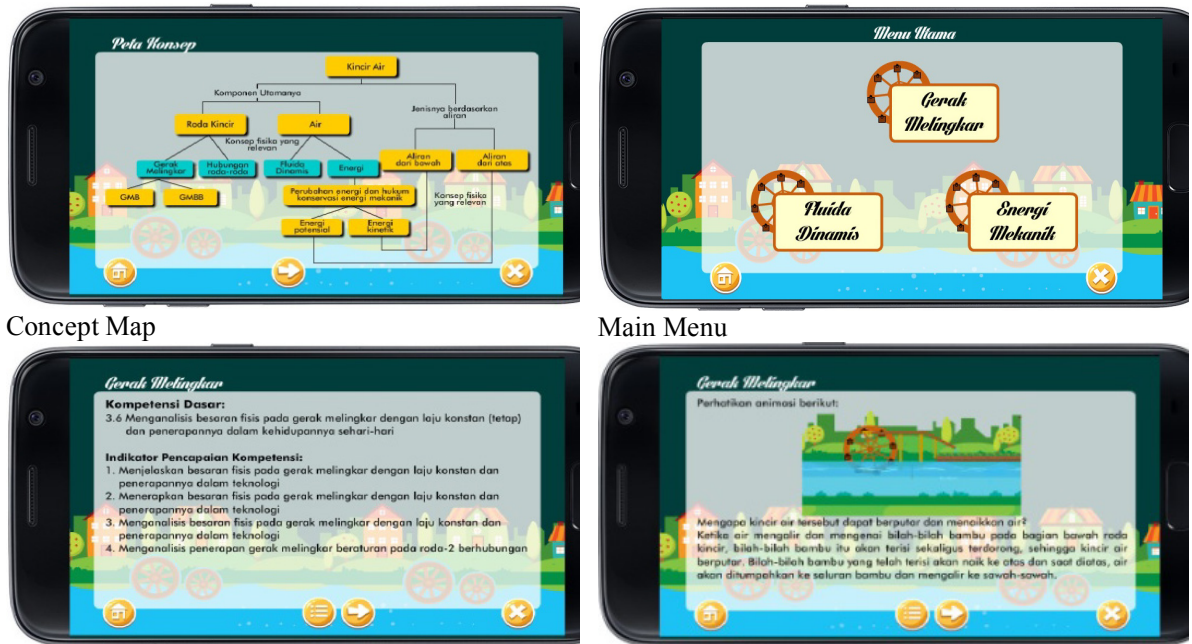

Main Menu

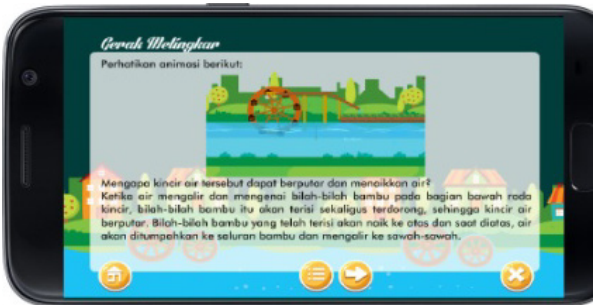

Basic Competencies

Material

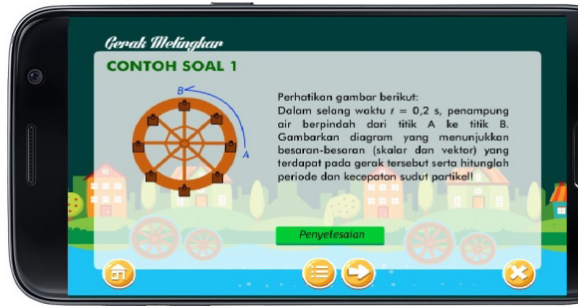

Problem Solving Example

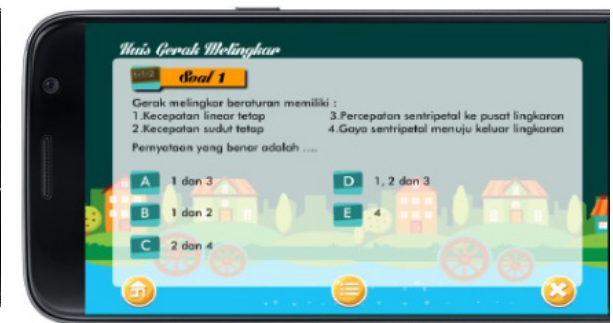

Quiz

Fig. 2. Display of the Learning Media 


\subsection{Feasibility Test Results}

The learning media that has been developed was tested for feasibility to answer the first research question. Feasibility tests were conducted through expert validation and field testing. In expert validation, validators assessed learning media quality in term of its media/appearance and material/ substance. The assessment results both from the materials aspect and media aspect are categorized as 'very good'. Nevertheless, there were some point to be revised from mobile learning according to validator suggestion. The expert validation assessment results are shown in Table 4.

Table 4. Expert Validation Results

\begin{tabular}{|c|c|c|c|c|}
\hline \multicolumn{2}{|c|}{ Assessment Aspects } & Score Interval & Average Scores & Category \\
\hline \multirow{10}{*}{ Materials } & \multirow{5}{*}{ Learning } & $X>21$ & \multirow{5}{*}{22} & \multirow{5}{*}{ Very Good } \\
\hline & & $17<X \leq 21$ & & \\
\hline & & $13<X \leq 17$ & & \\
\hline & & $9<X \leq 13$ & & \\
\hline & & $X \leq 9$ & & \\
\hline & \multirow{5}{*}{ Materials } & $X>37,8$ & \multirow{5}{*}{39} & \multirow{5}{*}{ Very Good } \\
\hline & & $30,6<X \leq 37,8$ & & \\
\hline & & $23,4<X \leq 30,6$ & & \\
\hline & & $16,2<X \leq 23,4$ & & \\
\hline & & $X \leq 16,26$ & & \\
\hline \multirow{10}{*}{ Media } & \multirow{5}{*}{$\begin{array}{l}\text { Audio Visual } \\
\text { Display }\end{array}$} & $X>46,2$ & \multirow{5}{*}{51} & \multirow{5}{*}{ Very Good } \\
\hline & & $37,4<X \leq 46,2$ & & \\
\hline & & $28,6<X \leq 37,4$ & & \\
\hline & & $19,8<X \leq 28,6$ & & \\
\hline & & $X \leq 19,8$ & & \\
\hline & \multirow{5}{*}{$\begin{array}{l}\text { Software En- } \\
\text { gineering }\end{array}$} & $X>21$ & \multirow{5}{*}{23} & \multirow{5}{*}{ Very Good } \\
\hline & & $17<X \leq 21$ & & \\
\hline & & $13<X \leq 17$ & & \\
\hline & & $9<X \leq 13$ & & \\
\hline & & $X \leq 96$ & & \\
\hline
\end{tabular}

Revised learning media was used in the limited test. From the students' questionnaires on the limited test, the learning media is categorized as 'good' from the aspect of materials/learning and 'very good' from the aspect of media operational display. Based on the results of expert validation and this limited test, the learning media is feasible to use. The use of learning media that is mobile or m-learning is considered capable and appropriate to facilitate the audio visual display of the vector and diagram representation. Table 5 shows the limited test results. 
Table 5. Limited test Results

\begin{tabular}{|c|c|c|c|}
\hline Assessment Aspects & Score Interval & Average Scores & Category \\
\hline \multirow{5}{*}{ Materials/Learning } & $X>21$ & \multirow{5}{*}{20.69} & \multirow{5}{*}{ Good } \\
\hline & $17<X \leq 21$ & & \\
\hline & $13<X \leq 17$ & & \\
\hline & $9<X \leq 13$ & & \\
\hline & $X \leq 9$ & & \\
\hline \multirow{5}{*}{ Display/Media Operation } & $X>42$ & \multirow{5}{*}{43.87} & \multirow{5}{*}{ Very Good } \\
\hline & $34<X \leq 42$ & & \\
\hline & $26<X \leq 34$ & & \\
\hline & $18<X \leq 26$ & & \\
\hline & $X \leq 18$ & & \\
\hline
\end{tabular}

\subsection{Representation Abilities Improvement}

Answering the second research question, the learning media then tested in field testing to find out whether the learning media can improve the vector representation and diagram representation abilities. This field test was conducted on 25 students in the control class and 25 students in the experimental class. From pre-post test of both class, gain score of each class can be determined and interpreted according to Table 2.

The results of this test showed that or vector representation ability, both classes gain score were categorized as 'medium'. For the diagram representation ability, gain score of control class was in 'medium' category. Meanwhile, gain score of the experimental class was in 'high' category. In general, the gain scores from both class indicated that the improvement of representation ability of experiment class is higher than control class. The pre-test and post-test results that obtained the gain value of both classes are shown in Table 6 and 7.

Table 6. Field Test Gain Data for Vector Representation Ability

\begin{tabular}{|l|l|l|l|l|}
\hline \multicolumn{1}{|c|}{ Class } & \multicolumn{2}{c|}{$\begin{array}{c}\text { Vector Representation } \\
\text { Ability }\end{array}$} & \multicolumn{1}{c|}{ Gain } & \multicolumn{1}{c|}{ Criteria } \\
\hline Control & 8.00 & 52.80 & 0.48 & Medium \\
\hline Experimental & 11.20 & 62.13 & 0.57 & Medium \\
\hline
\end{tabular}

Table 7. Field Test Gain Data for Diagram Representation Ability

\begin{tabular}{|l|l|l|l|l|}
\hline \multicolumn{1}{|c|}{ Class } & \multicolumn{1}{c|}{$\begin{array}{c}\text { Diagram Representation } \\
\text { Ability }\end{array}$} & Gain & Criteria \\
\hline Control & 0.00 & 62.93 & 0.63 & Medium \\
\hline Experimental & 0.53 & 69.87 & 0.70 & High \\
\hline
\end{tabular}

In term of number of problem-solving steps conducted by the students, there is a difference between both classes. The frequency of students performing problem solving with a number of steps of vector representation and diagram representation is shown in Figure 3 and Figure 4. 


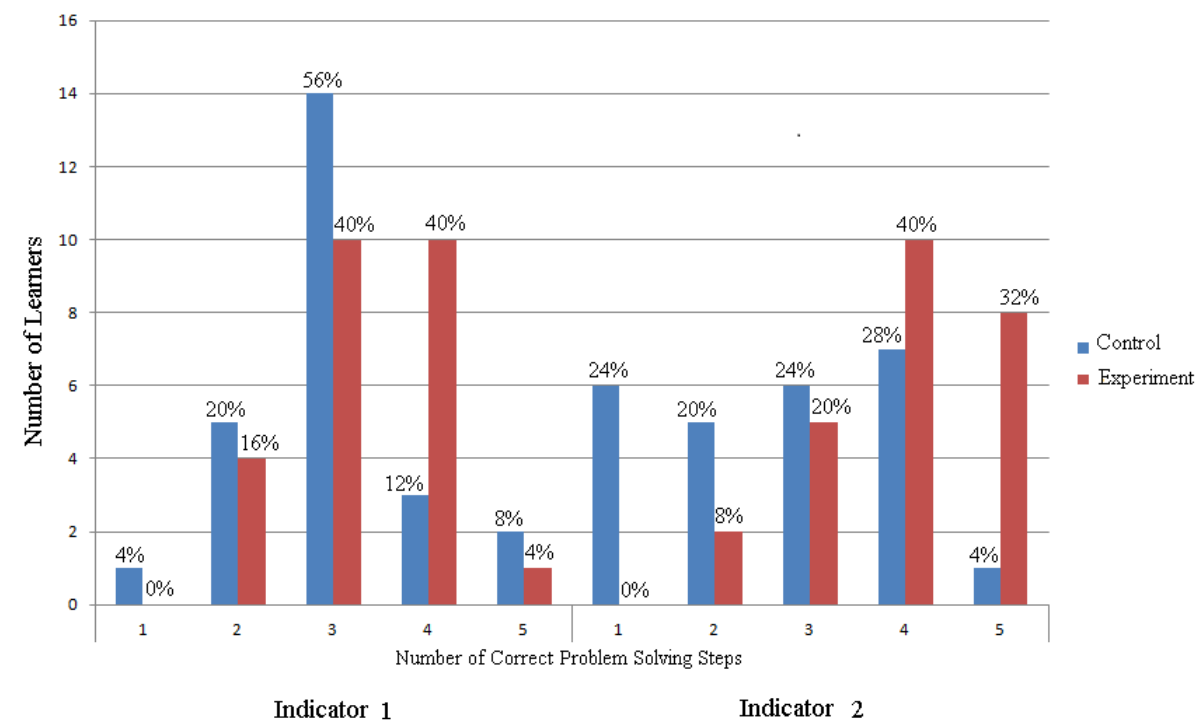

Fig. 3. Graph of the Number of Students Conducting Correct Problem Solving Steps for Vector Representation

Figure 3 shows that there is a difference in the distribution of the number of students who solve the problem by using vector representation with a specific numbers of steps. For indicator 1 (describe and identify the scalar and vector quantities) most of the students in the control class that is by $56 \%$ only performed 3 steps correctly. As for the students in the experimental class, $40 \%$ students performed 4 steps correctly. What is interesting from the graph is the number of the students in the control class who performed 5 steps correctly is $4 \%$ higher than the experimental Overall, there were more numbers of experimental class students who performed 4 and 5 steps of problem solving than control class.

Indicator 2 is the ability to describe and calculate the vector quantity correctly for solving the problem. For this indicator as shown in Figure 3, the experimental class students perform it better than the control class. This can be seen from the high number of experimental class students who perform 4 and 5 problem solving steps, $40 \%$ to $32 \%$. This number is quite different from that of control class that is $28 \%$ and $4 \%$ for 4 and 5 problem solving steps. In fact, the number of control class students who only perform 1 step is quite high. This indicates that after the learning, the experimental class students have the ability to describe and calculate the vector quantity correctly to perform better problem solving than the control class students. 


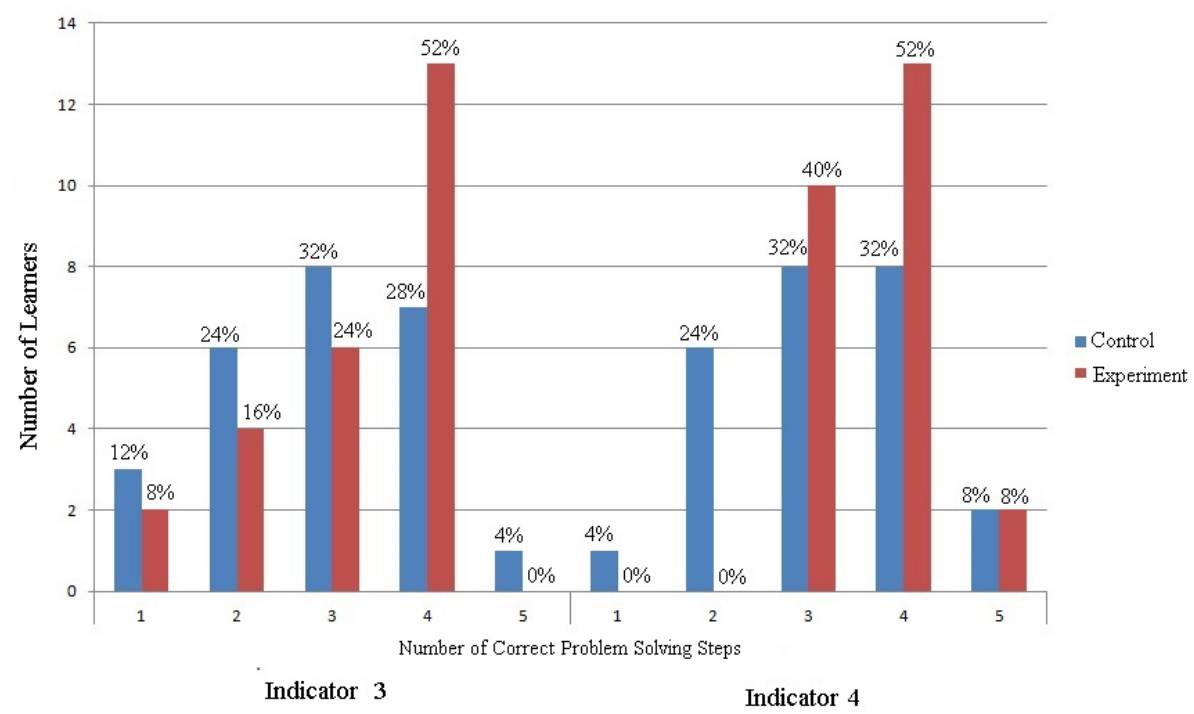

Fig. 4. Graph of the Number of Students Conducting Correct Problem Solving Steps for Diagram Representation

Indicator 3 measured student ability to interpret information from a representation into diagram representation to solve the problem. From the data obtained, what is interesting is that most of the experimental class students $(52 \%)$ only perform 4 steps to solve the problem and nobody performs it with the complete 5 steps. As for the control class, it is the same as the previous 2 indicators which indicate a normal curve; in which the majority of the students perform 3 steps to solve the problem. Lastly, Indicator 4 measured ability to use a diagram representation to determine the interactions in the system. In this ability, the graph follows the same pattern as the graph on indicator 3 . The experimental class has a distribution of students who perform more numbers of problem solving steps than the control class. Most of the control class students $(52 \%$ and $8 \%$ ) perform 4 and 5 steps to solve the problem correctly and nobody performs just 1 and 2 steps. This shows that after learning with the learning media, the experimental class students can use the diagram representation to better determine the interaction in the system compared to the control class students.

Overall, from Figures 3 and 4, it can be observed that the frequency of the experimental class students performing complete problem-solving steps ( 4 and 5 steps) is higher than the control class students. For some indicators, there were even no students who only perform 1 and 2 problem solving steps. This difference is more obvious in the diagram representation ability. In the control class, the frequency distribution is more to form a normal curve, students perform mostly 3 steps of problem solving. This suggests that the use of the android-assisted learning media which is based on local wisdom in the experimental class can help students to solve the problems with more steps (4 and 5 steps) than the control class students. 
The field test results obtained show a higher level of the vector representation and diagram representation abilities of the students who use the developed learning media which is based on local wisdom. This positive outcome indicates that local wisdom can be well integrated in learning. This is in line with the studies conducted by Suastra, Tika and Kariasa [33]. Their study developed the competence of science learning based on traditional local wisdom such as measurement with traditional methods and traditional medicine. From the study results, it is found that the learning model which is based on local wisdom is quite effective in improving the students' basic competence of physics science both in the academic achievement and scientific performance.

The developed learning media which is based on local wisdom is one of the efforts to display the contextual learning. Suastra [34] states that local wisdom can accommodate the needs of illustrations in science learning because of their interrelationships in the daily life. In terms of solving the problem, Moreno, Ozogul and Reisslein [35] added that in order to improve the problem-solving ability of the students, the diagram representation used remains connected or emphasized in their concrete form. Presenting physics consepts through the context of the waterwheel as local wisdom helps the students to understand the concepts in a concrete and a contextual way. Therefore their vector and diagram abilities can be improved.

\section{Conclusion}

This study was conducted to develop an android-assisted learning media which is based on local wisdom which is feasible and can improve the students' abilities of vector representation and diagram representation. The results of the study show that through expert validation and field testing, the learning media is feasible and categorized as 'very good'. Furthermore, the use of learning media in field test obtained higher gain score in the experimental class than the control class. This shows that the developed android-assisted learning media which is based on local wisdom waterwheel can improve the students' abilities of vector representation and diagram representation.

\section{$9 \quad$ References}

[1] Khaddage, F., Lattemann, C., \& Bray, E. (2011, March). Mobile apps integration for teaching and learning.(Are Teachers Ready to Re-blend?). In Society for Information Technology $\&$ Teacher Education International Conference (pp. 2545-2552). Asso-ciation for the Advancement of Computing in Education (AACE).

[2] Walker, L. (2011). My teacher is an Android: Engaging students through an Android application, Proceedings of ASCILITE - Australian Society for Computers in Learn-ing in Tertiary Education Annual Conference 2011 (1270-1274

[3] Friedel, H., Bos, B., Lee, K. S., \& Smith, S. (2013). Smartphones-Smart Students: A Review of the Literature. In Society for Information Technology \& Teacher Educa-tion International Conference (Vol. 2013, No. 1, pp. 1862-1868).

[4] Babiker, M., \& Elmagzoub, A. (2015). For Effective Use of Multimedia in Education, Teachers Must Develop Their Own Educational Multimedia Applications. Turkish Online Journal of Educational Technology-TOJET, 14(4), 62-68. 
Paper-Development of Physics Mobile Learning Based on Local Wisdom to Improve Vector...

[5] Ktoridou, D., \& Eteokleous, N. (2005). Adaptive m-learning: technological and peda-gogical aspects to be considered in Cyprus tertiary education. Recent research devel-opments in learning technologies, 676-683.

[6] Shanmugapriya M \& Tamilarasi (2011), Designing An M-Learning Application For A Ubiquitous Learning Environment In The Android Based Mobile Devices Using Web Services, Indian Journal of Computer Science and Engineering (IJCSE) 2011, 2. 1

[7] Leeds, B. (2011, June). Creating Open Educational Resources for Mobile Phones. In EdMedia: World Conference on Educational Media and Technology (pp. 457-460). Association for the Advancement of Computing in Education (AACE).

[8] Kesiman, M. W. A., \& Agustini, K. (2013, July). The Implementation of Hypertext-based Learning Media for a Local Cultural Based Learning. In Proceedings of the In-forming Science and Information Technology Education Conference (pp. 377-385). Informing Science Institute.

[9] Rosengrant, D., Van Heuvelen, A., \& Etkina, E. (2009). Do students use and under-stand free-body diagrams?. Physical Review Special Topics-Physics Education Re-search, 5(1), 010108. https://doi.org/10.1103/PhysRevSTPER.5.010108

[10] Brown J (2010). Can you hear me now? In T+D, Vol. 64, No. 2, pp 28-30

[11] Khaddage, F. \& Knezek, G. (2011). Device Independent Mobile Applications for Teaching and Learning: Challenges, Barriers and Limitations. Proceedings of Global Learn 2011 (17)

[12] Hwang, G. J., Wu, P. H., Zhuang, Y. Y., \& Huang, Y. M. (2013). Effects of the inquirybased mobile learning model on the cognitive load and learning achievement of stu-dents. Interactive learning environments, 21(4), 338-354. https://doi.org/10.1080/10494820.2011. $\underline{575789}$

[13] Lubis, I. R., \& Ikhsan, J. (2015). Pengembangan Media Pembelajaran Kimia Berbasis Android Untuk Meningkatkan Motivasi Belajar Dan Prestasi Kognitif Peserta Didik Sma. Jurnal Inovasi Pendidikan IPA, 1(2), 191-201. https://doi.org/10.21831/jipi.v1i2.7504

[14] Cheong Cheng, Y. (2004). Fostering local knowledge and human development in globalization of education. International Journal of Educational Management, 18(1), 7-24. https://doi.org/10.1108/09513540410512109

[15] Shukla, S., \& Gardner, J. S. (2006). The Role of Traditional Ecological Knowledge in Education for Community-Based Resource Management. The University of Manitoba. URL http://eprints2. dlib. indiana. edu/archive/00001488/00/Shukla_Role_040511_Paper223. pdf Accessed, 8(1), 06.

[16] Meliono, I. (2016). Understanding the nusantara thought and local wisdom as an as-pect of the Indonesian education. TAWARIKH, 2(2).

[17] Liliweri, A., (2014). Pengantar Studi Kebudayaan. Penerbit Nusa Media. Bandung.

[18] Machmud, M. (2013). Heritage Media and Local Wisdom of Indonesian Society. Global Journal of Human-Social Science Research, 13(6).

[19] Koentjaraningrat. (1984). Kebudayaan Jawa: Seri Etnografi Indonesia. Balai Pustaka. Jakarta.

[20] Azzizahwati, Maaruf, Z., Yassin, R., et al. (2014). Pengembangan Modul Pembelajaran Fisika SMA Berbasis Kearifan Lokal untuk Meningkatkan Hasil Belajar Peserta didik, Prosiding. Pertemuan Ilmiah XXIX HFI Jateng \& DIY, Yogyakarta 25 April 2015 ISSN : 08530823

[21] Castagno, A. E., \& Brayboy, B. M. J. (2008). Culturally responsive schooling for In-digenous youth: A review of the literature. Review of Educational Research, 78(4), 941-993. https://doi.org/10.3102/0034654308323036 
Paper—Development of Physics Mobile Learning Based on Local Wisdom to Improve Vector...

[22] Reyes-García, V., Kightley, E., Ruiz-Mallén, I., Fuentes-Pelaez, N., Demps, K., Huanca, T., $\&$ M. (2010). Schooling and local environmental knowledge: Do they complement or substitute each other?. International Journal of Educational Development 30 (2010) 305-313 https://doi.org/10.1016/j.ijedudev.2009.11.007

[23] Thaman, K. H. (2002). Shifting sights: the cultural challenge of sustainabil-ity. International Journal of Sustainability in Higher Education, 3(3), 233-242. https://doi.org/10.1108/146 $\underline{76370210434697}$

[24] McCarter, J., \& Gavin, M. C. (2011). Perceptions of the value of traditional ecological knowledge to formal school curricula: opportunities and challenges from Malekula Is-land, Vanuatu. Journal of Ethnobiology and Ethnomedicine, 7(1), 38. https://doi.org/10.1186/1746-4269-7-38

[25] Barniol, P., \& Zavala, G. (2010, October). Vector addition: Effect of the context and position of the vectors. In C. Singh, M. Sabella, \& S. Rebello (Eds.), Aip conference proceedings (Vol. 1289, No. 1, pp. 73-76). AIP.

[26] Kustusch, M. B. (2016). Assessing the impact of representational and contextual problem features on student use of right-hand rules. Physical Review Physics Educa-tion Research, 12(1), 010102 https://doi.org/10.1103/PhysRevPhysEducRes. 12.010102

[27] Thiagarajan, S, Semmel, D. S, \&Semmel, M. L, (1974). Others Instructional Devel-opment For Training Teachers Ofexceptional Children: A Sourcebook. Washington, D. C: National Center For Improvement Of Educationalsystems.

[28] Aguirre, J., \& Erickson, G. (1984). Students' conceptions about the vector characteris-tics of three physics concepts. Journal of Research in Science Teaching, 21(5), 439-457. https://doi.org/10.1002/tea.3660210502

[29] Knight, R. D. (1995). The vector knowledge of beginning physics students. The phys-ics teacher, 33(2), 74-77. https://doi.org/10.1119/1.2344143

[30] Nguyen, N. L., \& Meltzer, D. E. (2003). Initial understanding of vector concepts among students in introductory physics courses. American journal of physics, 71(6), 630-638. https://doi.org/10.1119/1.1571831

[31] Larkin, J. H., \& Reif, F. (1979). Understanding and teaching problem-solving in phys-ics. European Journal of Science Education, 1(2), 191-203. https://doi.org/10.1080/01405287 $\underline{90010208}$

[32] Etkina, E., Van Heuvelen, A., White-Brahmia, S., Brookes, D. T., Gentile, M., Murthy, S., ... \& Warren, A. (2006). Scientific abilities and their assessment. Physical Review special topics-physics education research,2(2), 020103. https://doi.org/10.1103/PhysRev STPER.2.020103

[33] Suastra, I. W., Tika, K., \& Kariasa, N. (2011). Efektivitas model pembelajaran sains berbasis budaya lokal untuk mengembangkan kompetensi dasar sains dan nilai kea-rifan lokal di SMP. Jurnal Penelitian dan Pengembangan Pendidikan, 5(3), 258-273.

[34] Suastra, I. W. (2005). Merekonstruksi Sains Asli (Indigenous Science) dalam Rangka Mengembangkan Pendidikan Sains Berbasis Budaya Lokal di Sekolah: Studi Etnosains pada Masyarakat Penglipuran Bali (Doctoral dissertation, Universitas Pen-didikan Indonesia).

[35] Moreno, R., Ozogul, G., \& Reisslein, M. (2011). Teaching with concrete and abstract visual representations: Effects on students' problem solving, problem representa-tions, and learning perceptions. Journal of Educational Psychology, 103(1), 32. https://doi.org/10.1037/ $\underline{\mathrm{a} 0021995}$ 
Paper-Development of Physics Mobile Learning Based on Local Wisdom to Improve Vector...

\section{Authors}

Miftahul Husna is master student in Physics Education at Universitas Negeri Yogyakarta, Indonesia in 2017

Heru Kuswanto is an Associate Professor in the Department of Physics Education, Faculty of Mathematics and Natural Sciences, Universitas Negeri Yogyakarta. Indonesia. He passed the master program from Gadjahmada University, Indonesia. Doctoral degree was obtained from Université Jean Monnet de Saint Etienne, France.

Article submitted 17 April 2018. Resubmitted 13 August 2018. Final acceptance 23 October 2018. Final version published as submitted by the authors. 